\title{
The Different Perceptions of Public and Private Hospital Staff on Comprehensive Neonatal Obstetric Care
}

\author{
Winda Azmi Meisari*
}

*Correspondence Author: winda.ams@gmail.com

*Nunukan Puskesmas, Nunukan City, Kalimantan Utara. Indonesia

\begin{tabular}{l}
\hline I N D E X I N G \\
\hline Keywords: \\
PONEK; \\
HR; \\
Organization; \\
Hospital; \\
Medical personnel;
\end{tabular}

Kata Kunci:

PONEK;

$S D M$;

Organisasi;

Rumah Sakit;

Tenaga Medis;

\begin{abstract}
A B S T R A C T
This study discusses the staff's understanding of an existing maternal and neonatal program in Indonesia, namely the PONEK (Comprehensive Neonatal Emergency Obstetrics Services) program which is specifically held in Government Hospital or Private Hospital which is designated as PONEK hospital, research This focuses on comparing the performance of staff to the PONEK program of the hospital. The role of medical staff in running a program of health organizations is very influential in the success of a health program and service delivery. PONEK is a government program in order to minimize health problems in Indonesia, especially maternal and infant morbidity. This study aims to see differences in staff perceptions related to understanding the performance of ponek program. Method: The total number of samples in this study were 41 respondents (21 respondents Government Hospital and 19 respondents Private Hospital), statistical analysis used in this study is Mann Whitney. Result: Of the 6 factors that affect the performance, there are 2 factors that have significant difference, that is cooperation factor with $p$ value $0,01<\mathbf{a}(0,05)$ and support of superior with $\mathrm{p}$ value $0,024<\mathrm{a}(0,05)$. Conclusion: From the above results, the performance of private hospital employees compared to government hospitals has significant differences in terms of cooperation factors and support factors of supervisors.
\end{abstract}

\begin{abstract}
Penelitian ini membahas tentang pemahaman staf terhadap suatu program maternal dan neonatal yang ada di Indonesia yaitu program PONEK (Pelayanan Obstetri Neonatal Emergensi Komprehensif) yang program tersebut khusus diselenggarakan di Rumah Sakit Pemerintah atau Rumah Sakit Swasta yang rumah sakit tersebut ditunjuk sebagai rumah sakit PONEK, penelitian ini berfokus pada perbandingan kinerja staff terhadap program PONEK rumah sakit. Peran staf medis dalam menjalankan suatu program organisasi kesehatan sangat berpengaruh dalam keberhasilan suatu program kesehatan dan pemberian pelayanan. PONEK merupakan program pemerintah dalam rangka meminimalisir masalah kesehatan yang ada di Indonesia khususnya angka kematia ibu dan bayi. Penelitian ini bertujuan untuk melihat perbedaan persepsi staf yang berkaitan dengan pemahaman kinerja program ponek. Metode : Total jumlah sampel pada penelitian ini adalah 41 responden (21 responden RS Pemerintah dan 19 responden $R S$ Swasta), analisi statistik yang digunakan pada penelitian ini adalah Mann Whitney. Hasil : Dari 6 faktor yang mempengaruhi kinerja, terdapat 2 faktor yang memiliki perbedaan signifikan, yaitu faktor kerjasama dengan nilai $p$ $0,01<\boldsymbol{a}(0,05)$ dan dukungan atasan dengan nilai p 0,024<a(0,05). Kesimpulan : Dari hasil tersebut kinerja pegawai rumah sakit swasta dibanding rumah sakit pemerintah memiliki perbedaan signifikan dalam hal faktor kerjasama dan faktor dukungan atasan.
\end{abstract}

C) 2017 JMMR. All rights reserved

\section{INTRODUCTION}

According to UNICEF (2012) study, the case of maternal mortality in Indonesia is still high for ASEAN level. The chart result of maternal mortality trends of several ASEAN countries shows in 1990 - 2010, Indonesia is still high compared to Malaysia, Thailand, Philippines, Vietnam and Myanmar. So at the end of the 2015 Millennium Development Goals (MDGs) target, Indonesia's results are not in line with the expected target, Furthermore Indonesia is currently working with an advanced program called Sustainable Development Goals (SDGs). ${ }^{1}$ 


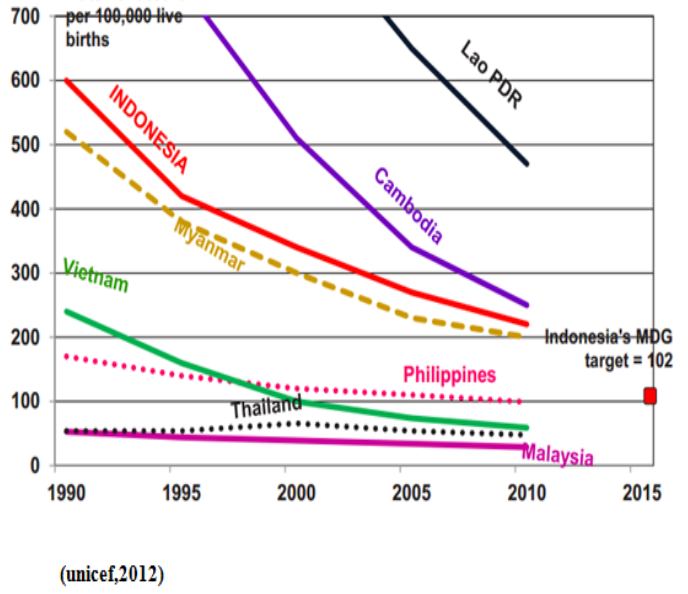

According to the Kementerian Kesehatan RI (2015) from the IDHS data in 2012 is known AKI of 359 / 100,000 live births and this figure is quite high compared to the 2007 AKI 228 / 100,000 live births. Because of that Indonesia continues to strive to improve the quality of its services through various programs to reduce maternal mortality, innovative breakthroughs are able to cope with the main causes of maternal mortality, with quick service responsiveness in making decisions, is expected to help the government to reduce maternal mortality. ${ }^{2}$

The grade segments of the population in many country enhancing to developing and deprived of a fundamental right: access to basic health care. ${ }^{1}$ Without an appropriate and adequate health support and delivery system in place, its adverse effects will be felt in all other sectors to developing access of the economy. ${ }^{2}$ Therefore, organization must be develop the customer satisfaction factor. ${ }^{3}$

According to data from the Health Office of DIY in 2015, an increase in maternal mortality in 2011 until 2013 and a significant decline in 2014, that was from the year 2013 with the number of 204 / 100,000 live births dropped to $46 / 100,000$ live births in 2014 . The maternal mortality rate in 2014 compared with the MDGS target of $<102$ / 100,000 live births in 2015, then the city of Yogyakarta has been able to reach the target. This illustrates the results of the accelerated efforts to reduce maternal deaths that have been done in the last 3 years, however such efforts should still be continued to improve maternal health status.

In Bantul district itself maternal mortality rate in 2012 was 52.2 / 100,000 live births and in 2013 an increase in maternal mortality cases $96.83 / 100,000$ live births with the number of 13 cases, although it is still below the average target of AKI in 2013 with a large target of $100 / 100,000$ live births. ${ }^{4}$ Bantul regency government still needs to improve health service to improve maternal health status.
In 2005, the preparation of the guidebook of PONEK and technical guidance in 4 provinces as the initial step of the ponek program, and in 2007 the skills training for the PONEK team of district / city hospitals (pediatricians, obstetricians, midwives and nurses) all health networks, PONEK is a 24-hour Comprehensive Emergency Obstetric and Neonatal Service at the hospital, part of the maternal and neonatal emergency service referral system, which plays a role in reducing maternal and newborn mortality. The government hopes that with the PONEK hospital program can minimize health problems in Indonesia, one of them AKI and AKB. PONEK has different standards in each type of hospital, this is adjusted to the availability of facilities and personnel at each hospital. Key to the success of PONEK is the availability of health personnel according to competence, infrastructure, and reliable management. ${ }^{4}$

According to research of Ernawati et al (2013), found just $52.9 \%$ of HR Team RS has PONEK complete with optimized performance and $92 \%$ who have a human resources PONEK incomplete team has less than optimal performance, So that the completeness of the PONEK team is very influential on the performance that results on the implementation of PONEK in government hospitals in Indonesia. Hospitals with an incomplete PONEK team had a 1.78 -fold risk for having a less than optimal hospital performance compared to hospitals with a complete PONEK team. ${ }^{5}$

\section{RESEARCH METHOD}

The type of research used is analytic quantitative descriptive, in which this study describes the staff to the PONEK program based on factors affecting the performance of human resources in government hospitals and private hospitals, and the performance comparison between the PONEK team working in government hospitals and private hospitals by looking at staff's understanding of the PONEK program. The study population is the whole of staff working in government hospitals and private hospitals. The method used for sampling is total sampling, where the sample is all health workers who are a team of PONEK in government hospitals and private hospitals. In this study the selected staff to be sampled are the staff working in emergency department (RS Emergency Unit) of Government Hospital and Private Hospital, and the total result which fulfill the criteria of respondents above is 40 respondents from 58 samples, where as many as 21 respondents from Government Hospital and 19 respondents from Private Hospital. 
Data analysis was performed with SPSS.20.0 computerized system, statistical test used was Mann Whitney.

\section{RESULT AND DISCUSSION}

1. The distribution of the frequency of the staff's understanding of the PONEK program based on the HR and the Organization factor in public and private hospitals

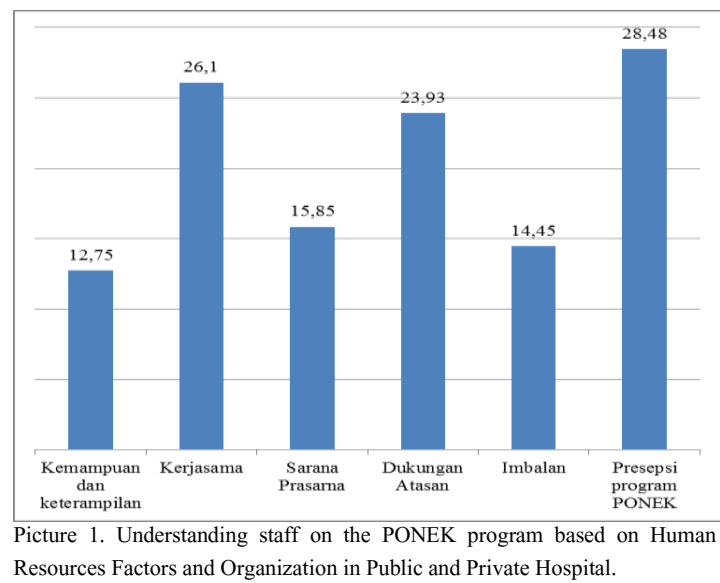

From the bar chart above, it can be understood that the staff's understanding of the PONEK program in terms of perceptions of the PONEK program whether at Bantul Government and Private Hospital is the highest with a mean of 28.48 so that it can be collected that the average staff working public and private hospitals are aware of the PONEK program, while the capacity and capability of each staff for both Government and Private Hospital in Bantul Regency is the lowest of the 6 variables used in this study with a mean of 12.75 , if averaged overall with scoring weight, results show that the average staff understanding of the PONEK program between government and private hospitals is very high.

2. The description of the frequency distribution of staff's understanding of the PONEK program based on HR and Organization factors in Government Hospitals



For the Government Hospital located in Bantul District, the staff's understanding of the PONEK program from the perspective of the PONEK program is the highest of all the variables used in this study and the lowest is the staff's perception of personal skills and skills, if averaged as a whole with scoring weight, the result shows that the average of staff's understanding of the PONEK program in Government House is very high.

3. The description of the frequency distribution of staff's understanding of the PONEK program based on HR and Organizational factors in Private Hospitals

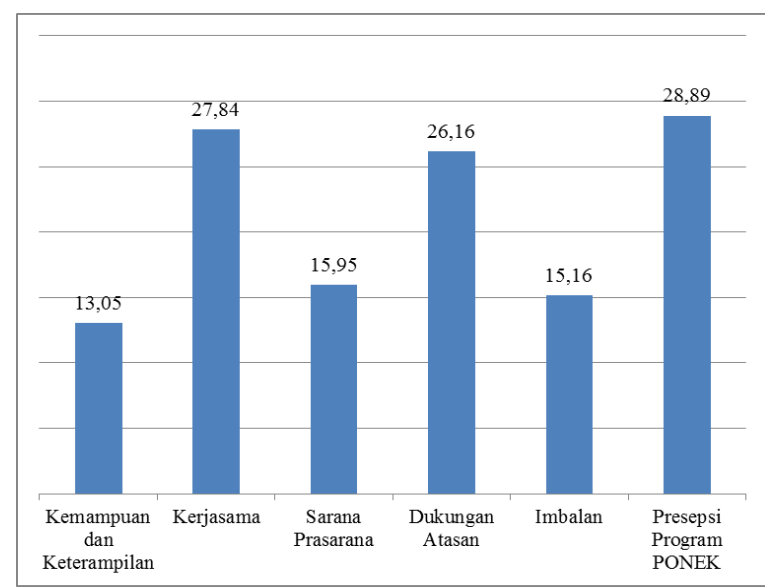

Picture 3. Understanding staff on the PONEK program based on Human Resources Factors and Organization in Private Hospital.

For the private hospitals located in Bantul District, the staff's understanding of the PONEK program in terms of PRCP program perception is the highest of all variables used in this study and the lowest is the staff perception of personal skills and skills, if averaged overall with scoring weight, the result shows that the average of staff's 
understanding on the PONEK program in private hospital is very high.

4. The assessment of respondents based on Abilities and skills of public hospitals and private hospitals

\begin{tabular}{cccc}
\hline Hospital & N & Mean Rank & Asymp. Sig \\
\hline Public & 21 & 19,26 & 0,475 \\
Private & 19 & 21,87 & \\
& 40 & & \\
\hline
\end{tabular}

Based on the results of the above analysis it is known that there is no significant difference in terms of ability and skill of staff between the two hospitals, namely Government Hospital and Private Hospital located in Bantul District, Yogyakarta with significance value 0,475> 0,05 .

5. The assessment of respondents based on factors cooperation of public hospital and private hospital

\begin{tabular}{cccc}
\hline Hospital & N & Mean Rank & Asymp. Sig \\
\hline Public & 21 & 16,05 & \\
Private & 19 & 25,42 & 0,01 \\
& 40 & & \\
\hline
\end{tabular}

Based on the results of the above analysis it is known that there are significant differences in terms of staff cooperation between the two hospitals mamely Government Hospital and Private Hospital located in Bantul District, Yogyakarta with significance value $0,01<0,05$.

6. The assessment of respondents based on factors infrastructure of public hospital and private hospital

\begin{tabular}{cccc}
\hline Hospital & N & Mean Rank & Asymp. Sig \\
\hline Public & 21 & 20,55 & \\
Private & 19 & 20,45 & 0,978 \\
& 40 & & \\
\hline
\end{tabular}

Based on the results of the above analysis it is known that there is no significant difference in terms of infrastructure facilities between two hospitals namely Government Hospital and Private Hospital located in Bantul district, Yogyakarta with significance value 0,978>0,05.
7. The assessment of respondents based on factors Supervisor Support of public hospital and private hospital

\begin{tabular}{cccc}
\hline Hospital & N & Mean Rank & Asymp. Sig \\
\hline Public & 21 & 16,57 & \\
& & & 0,024 \\
Private & 19 & 24,84 & \\
& 40 & & \\
\hline
\end{tabular}

Based on the results of the above analysis it is known that there are significant differences in terms of support of the supervisor between the two hospitals, namely Government Hospital and Private Hospital located in Bantul regency, Yogyakarta with a significance value of $0.024<0.05$

8. The assessment of respondents based on factors repayment of public hospital and private hospital

\begin{tabular}{cccc}
\hline Hospital & N & Mean Rank & Asymp. Sig \\
\hline Public & 21 & 18,67 & \\
& & & 0,287 \\
Private & 19 & 22,53 & \\
& 40 & & \\
\hline
\end{tabular}

Based on the results of the above analysis it is known that there is no significant difference in terms of rewards received by the staff between the two hospitals, namely Government Hospital and Private Hospital which is located in Bantul District, Yogyakarta with significance value $0,287>0,05$.

9. The assessment of respondents based on factors perception of public hospital and private hospital

\begin{tabular}{cccc}
\hline Hospital & N & Mean Rank & Asymp. Sig \\
\hline Public & 21 & 18,55 & 0,261 \\
Private & 19 & 22,66 & \\
& 40 & & \\
\hline
\end{tabular}

Based on the analysis above, it is known that there is no significant difference in terms of staff perception toward a program between the two hospitals, namely Government Hospital and Private Hospital located in Bantul District, Yogyakarta with significance value 0,261>0,05. 
From the research conducted on two different groups of public hospital and private hospitals, this study discusses the staff's understanding of a PONEK program that is held in each agency by looking at the factors that affect the performance and make comparisons on the two hospitals, there are 6 factors used in this research, and from 6 factors there are 2 factors that have significant difference that is cooperation factor with value $0,01<\mathbf{a}(0,05)$ and support of supervisor with value $0,024<\mathbf{a}(0,05)$. The differences may be influenced by personal staff and work environment. Where every staff has their own mission vision to their profession, good inter-professional communication and good organization organization system that support personal staff, because success of program objectives of the organization in running the program is strongly influenced by the performance of its staff, be it personal and team performance, and staff's understanding of the program held by the hospital. A study conducted by Al-Ahmadi (2009) on the performance of nurses performance, in his research found work performance correlated positively with organizational commitment, job satisfaction and personal and professional variables. ${ }^{6}$ Job satisfaction and organizational commitment are strong predictors of nurse performance. This study is also in accordance with Andini (2010) satisfaction of a job that has a positive influence on organizational commitment.

Communication between staff in public hospitals and private hospitals, private hospitals show better communications, which are influenced by several factors that affect staff performance. This shows that cooperation in private hospitals is better than government hospitals. In the research of Fitria et al (2016), researchers also conducted a study on the support of the head of the room in communication between staff, in this study also showed that support of superior or head of room in private hospital better than public hospital. ${ }^{7}$

Brunetto et al in 2010 in his research shows that private hospital nurses are more satisfied with their supervision, enjoying a higher morale of work and more committed to their organization. However, both groups were only slightly satisfied with the relationship between supervisors and subordinates, in his research also found that current management practices are not ideal for promoting effective working relationships. ${ }^{8}$

Good communication will affect the results of staff work to avoid conflict between health workers, as well as support of employers also affect the working relationship between staff for the better. Research on conflict management at Cyprus government hospital, $64 \%$ of respondents reported that they were never told about conflict management strategies, $60 \%$ of health care professionals reported workplace conflicts with other healthcare workers one to five times per week, $37 \%$ respondents stated that they devote 90 minutes (average value) of the work during their conflict resolution change, meaning managing the conflict could absorb 19\% working time each day. Basically. The majority of respondents agree that organizational issues and communication gaps are the main issues that create conflict. Avoidance and collaboration is a better strategy for conflict resolution, $36.6 \%$ and $37.5 \%$ respectively. Better communication, fair management practices and clear job descriptions and expectations may be needed to facilitate change and reverse the negative atmosphere. Further education in conflict management for doctors, nurses and their managers may also be needed. ${ }^{9}$

In general, in the research of these six factors (skills and skills, cooperation, infrastructure, support from superiors, rewards and perceptions), understanding of the skills and skills of staff working in hospitals, both government and private hospitals in the district of Bantul in managing the program PONEK is the lowest rank and unank understanding of staff perception toward program of PONEK in hospital in Bantul Regency area that is Government or Private Hospital is the highest order where the staff working in Bantul District Hospital on average understand the existence of the PONEK program. In the second order of cooperation between the teams in each hospital, third order of superiors support, the fourth order of means of prasana, and the fifth order is the reward. Maternal mortality in cities is lower than the maternal mortality rate in rural areas, and deaths in the post-natal period are the most dominant periods of the other period, where $61.8 \%$ of maternal deaths, when pregnant $20.5 \%$, when maternity $13.6 \%$ and the rest during miscarriage, according to investigators of health facilities that are able to PONEK hospital services is the best service for maternal mothers who require obstetric treatment and in general hospitals that have not PONEK have the ability better than PONED and Non-PONED. There is a difference in the role of birth attendant in PONED PHC with non PONED, but for other factors do not show the difference. Birth midwife helpers, have an important role to strengthen the good referral process is to prepare from the beginning if pregnancy complications found. ${ }^{10}$

Facilities that are not adequately equipped and compromised with the ability of the health system to reduce maternal and infant mortality and morbidity by affecting 
staff personally and professionally, which impedes timely and appropriate interventions. Improving stock control and equipment maintenance can benefit mothers and infants, not only by removing restrictions on the availability of care but also improving the working conditions of staff. ${ }^{11}$

In a study conducted at the Tengku Mansyur Hospital Tanjungbalai, the study found that the standard of care services in obstetric care unit obstetrics has not been met, both the number and criteria of personnel, and the implementation of staff development and educational programs are very poor and quality control has never been implemented, thus the organization management of the hospital does not run maximally this can affect the quality of service, while in running a program held in hospitals, especially the PONEK program. ${ }^{12}$

On the problem and prevention of delay in maternal referral in majene district, where the results indicate the problems caused in maternal referral is due to late decision by the family, limited transportation facilities, late calling midwife after difficulty of doing help childbirth, geography, distance and infrastructure, and limited ability of midwives or doctors in handling emergency cases. And prevention efforts are done by counseling on ante natal, home visits and practice of home delivery, mentoring, midwife accompanied by a shaman during labor. Notification is done earlier by family members, midwives perform labor monitoring by making a birth calendar inserted into the pocket so that if the delivery schedule is close they are monitoring to avoid delay in delivery assistance, referring to a more complete health facility by attaching a referral letter. ${ }^{13}$ Access to maternal services obtained by the community greatly affects the beneficiaries of existing health facilities, according to Adriana (2014) study, there is have a relationship between access to health services and the utilization of adequate maternity facilities, so the need for an overhaul of access to health services, especially the means of prasarna that support utilizing delivery services. ${ }^{14}$

According to Trisnantoro et al (2013) research, on the problems and challenges of puskesmas and regional hospitals in supporting the maternal referral system in Karimun district, there are still problems and challenges faced by Puskesmas and RSUD in supporting maternal referral processes such as facilities and equipment, the preparation of the RSUD as a hospital capable of PONEK, although 24 hour service activity is already running, lack of team cooperation between referral levels involving DHO, RSUD and Puskesmas, incomplete SOP, weak information system and referral flow by pass still found, the community in the referral system is very high, but labor with the Dukun is still found, according to the researcher this condition is more due to cultural factors. ${ }^{15}$

Staff are required to work maximally and provide the best service with the capabilities and skills of each staff in accordance with the profession undertaken by the staff, the work team is also required in every emergency action, any staff can make decisions according to their respective professions. staff, this is also supported by facilities that are provided by the hospital for the purpose of the PONEK program can be achieved and run in accordance with applicable regulations. Increasing the performance of health workers is needed, in accordance with Kuntjoro's (2005) research with the development of performance management (PMK) as a national strategy for improving clinical and nursing care, FMD is a simple and appropriate strategy to improve the quality of care, FMD can be seen as the initial strategy of applying governance clinical management. ${ }^{22}$

Performance of staff in the health care unit, if running well these performance in addition to maximize unit revenue and provide quality services with good integrity will greatly assist in the success of program PONEK, according to research Jongh et.al (2016) Benefits of integrating antenatal services with services others can be realized if the services provided, the design of the health system and in the process of integration of the sociopolitical context must be carefully considered as involving all stakeholders. These factors directly concern them as providers and recipients of health services in the constraints of the health system, as well as the broader socio-political environment in which ANC services. ${ }^{23}$ concluded that there is a great deal between the factors affecting the integrity of health services and benefits gained and in particular this has a direct bearing on the quality of MCH services.

In a study conducted at RSUP Prof.DR.R.D. Kandou about the PONEK service, the researcher concludes that the PONEK team of the hospital has implemented the activities of PONEK program in order to decrease the AKI and IMR according to the guidance of PONEK, it is seen from the data taken by the researcher about the PONEK service in the hospital, from the data one of these activities is IMD where in 2014 only 7\% of total spontaneous 1926 births and data until June 2015 IMD (Early Breastfeeding Initiation) reached $51 \%$ of total spontaneous births of 561 births. ${ }^{24}$ It can be seen that the government-run PONEK program is very helpful in hospitals in the process of $\mathrm{MCH}$ services, with the program, the performance of staff can be more focused with the support of a reliable human resource management system. 


\section{CONCLUSION}

Based on the results of research and discussion on 2 hospitals, namely government hospital and private hospital with total sample 40 respondents (21 respondents of government hospital and 19 respondent private hospital), it can be concluded as follows, there is no difference in skills and skills, perceptions, means of infrastructure, and rewards between government hospitals and private hospitals in the performance of the team driving the PONEK program, there is a significant difference in terms of cooperation and superiors support between government hospitals and private hospitals in the performance of the team driving the PONEK program, with a $\mathrm{p}$ value of $0.01<\mathrm{a}(0.05)$ for cooperation factor and support of supervisor with $\mathrm{p}$ value $0,024<\mathrm{a}(0.05)$.

\section{ACKNOWLEDGMENT}

Thanks to the hospital team of Public Hospital and Privat Hospital, especially the support team and the driving force of the PONEK program in the hospital which has been much help in the process of this research, So that this research can goes well and maximize. And thanks to the district government of Bantul city that gives support to this research, as well as the academic community and lecturers in this study who have provided much input and assistance in the process of developing this research.

\section{REFERENCE}

1. UNICEF. (2012) "Ringkasan Kajian Kesehatan Ibu dan

Anak"

https://www.unicef.org/indonesia/id/A5_B_Ringkasa

n_Kajian_Kesehatan_REV.pdf Date of access $19 / 10 / 2016$

2. Kementerian Kesehatan RI. "Laporan Akuntabilitas Kinerja Kemen-Kes Tahun 2014”. Penerbit Kemenkes, Jakarta 2015

3. Dinkes Kab.Bantul. "Profil Kesehatan Kab.Bantul". Penerbit Dinas Kesehatan Kab.Bantul 2014.

4. Kementerian Kesehatan RI. "Pedoman Penyelenggaraan PONEK 24 Jam di Rumah Sakit". Penerbit Kementrian Kesehatan, Jakarta 2012.

5. Ernawati, D. S. D. C. (2013). "Determinan Kinerja Pelayanan Kesehatan Ibu Dan Anak Di Rumah Sakit
Pemerintah Indonesia (Analisis Data Rifaskes 2011”). Jurnal Kebijakan Kesehatan Indonesia, 2(04).

6. Al-Ahmadi, H. (2009). Factors affecting performance of hospital nurses in Riyadh Region, Saudi Arabia. International Journal of Health Care Quality Assurance, 22(1), 40-54.

7. Fitria, N., \& Shaluhiyah, Z. (2016). "Analisis Pelaksanaan Komunikasi Terapeutik Perawat di Ruang Rawat Inap RS Pemerintah dan RS Swasta”. Jurnal Promosi Kesehatan Indonesia, 9(2), 183-195.

8. Brunetto, Y., Farr-Wharton, R., \& Shacklock, K. (2010). "The impact of supervisor-subordinate relationships on morale: implications for public and private sector nurses' commitment". Human Resource Management Journal, 20(2), 206-225.

9. Pavlakis, A., Kaitelidou, D., Theodorou, M., Galanis, P., Sourtzi, P., \& Siskou, O. (2011). "Conflict management in public hospitals: the Cyprus case". International nursing review, 58(2), 242-248.

10. Irianto, J., \& Suharjo, S. (2016). "The Contribution of Public Health Center to Reducing Maternal Mortality". Buletin Penelitian Sistem Kesehatan, 19(1), 1-9.

11. Penfold, S., Shamba, D., Hanson, C., Jaribu, J., Manzi, F., Marchant, T., ... \& Schellenberg, J. A. (2013). Staff experiences of providing maternity services in rural southern Tanzania-a focus on equipment, drug and supply issues. BMC health services research, 13(1), 61.

12. Ritonga, N. A., \& Hasanbasri, M. (2007). "Manajemen Unit Gawat Darurat pada Penanganan Kasus Kegawatdaruratan Obstetri di Rumah Sakit Umum Tengku Mansyur Tanjung Balai”. Universitas Gadjah Mada Yogyakarta:Working Paper Series, 13, 1-10.

13. Irasanty, G., Hasanbasri, M., \& Hakimi, M. (2008). "Efforts to minimize delays in maternal referral in Majene District-Indonesia (Pencegahan Keterlambatan Rujukan Maternal di Majene Indonesia)”. Indonesian Journal of Health Service Management (Jurnal Manajemen Pelayanan Kesehatan), 11(3), 122-129.

14. Trisnantoro, L., \& Noor Zaenab, S. (2013). "Problem dan tantangan puskesmas dan rumah sakit umum daerah dalam mendukung sistem rujukan maternal di 
kabupaten Karimun provinsi Kepri tahun 2012". Jurnal Kebijkan Kesehatan Indonesia Vol 2.

15. Syed Saad Andaleeb. 2000. Public and private hospitals in Bangladesh: service quality and predictors of hospital choice. HEALTH POLICY AND PLANNING; 15(1): 95-102.

16. Syed Saad Andaleeb. 2001. Service quality perceptions and patient satisfaction: a study of hospitals in a developing country. Social Science \& Medicine 52 (2001) 1359-1370.

17. Figen Ye_ilada and Ebru Direktor. 2010. Health care service quality: A comparison of public and private hospitals. African Journal of Business Management Vol. 4(6), pp. 962-971.

18. Adriana, N (2014). Access to Health Service related to Use of Antenatal Care Facilities at the Kawangu Health Centre, East Sumba. Public Health and Preventive Medicine Archive, 2(2).

19. Andini, R. (2010). Analisis Pengaruh Kepuasan Gaji, Kepuasan Kerja, Komitmen Organisasional Terhadap Turnover Intention (Studi Kasus Pada Rumah Sakit Roemani Muhammadiyah Semarang) http://jurnal.unpand.ac.id/index.php/dinsain/article/vie w/54, Vol 8, No 16 (2010), date of access 23 November 2019

20. Dinkes DIY. "Profil Kesehatan Tahun 2015 Kota Yogyakarta (Data Tahun 2014)”. Penerbit Dinkes DIY, Yogyakarta 2015.

21. Kepmenkes No.129 Tahun 2008 Standar Pelayanan Minimal Rumah Sakit

22. Kuntjoro, T. (2005). "Pengembangan manajemen kinerja perawat dan bidan sebagai strategi dalam peningkatan mutu klinis”. Jurnal Manajemen Pelayanan Kesehatan, 8(03).

23. Jongh, T. E., Gurol-Urganci, I., Allen, E., Jiayue Zhu, N., \& Atun, R. (2016). "Barriers and enablers to integrating maternal and child health services to antenatal care in low and middle income countries". BJOG: An International Journal of Obstetrics \& Gynaecology, 123(4), 549-557.

24. Kaligis, V. R., \& Sondakh, J. M. (2016). "Data Pelayanan Obstetri Neonatal Emergensi Komprehensif (Ponek) Di Rsup Prof. Dr. Rd Kandou Periode Januari 2014-Juni 2015”. e-CliniC, 4(1). 